\title{
APPLICATION OF VIBROACOUSTIC DIAGNOSTICS TO EVALUATION OF WEAR OF FRICTION PADS RAIL BRAKE DISC
}

\section{ZASTOSOWANIE DIAGNOSTYKI WIBROAKUSTYCZNEJ W OCENIE ZUŻYCIA OKŁADZIN CIERNYCH KOLEJOWEGO HAMULCA TARCZOWEGO*}

\begin{abstract}
Vibrationacoustic diagnostics is increasingly used in new technical facilities to assess their condition. The main advantages of this diagnosis is the easiness of measurement, high speed transmission of information, the opportunity to assess the state of the whole or the individual components and high information content of the signal. All these features make it also possible to use WA diagnostic to assess the state of the braking system components. The article gives the possibility of determining the use of disc brake friction elements. This can be done on the basis of the analysis of vibration accelerations signals generated by the brake friction pads. The article presents diagnosis regression models [15] based on the analysis of vibration acceleration signals in the field of amplitude and frequency.
\end{abstract}

Keywords: rail brake disc, vibroacoustic diagnostics, amplitude characteristics, frequency analysis.

\begin{abstract}
Diagnostyka wibroakustyczna ze względu na swoje zalety znajduje coraz to nowe zastosowania w obiektach technicznych do oceny ich stanu. Główne zalety tej diagnostyki to łatwość pomiaru, duża szybkość przekazywania informacji, możliwość oceny stanu catego obiektu lub poszczególnych elementów oraz duża zawartość informacji w sygnale. Wszystkie te zalety sprawiają, że również możliwe jest zastosowanie diagnostyki WA do oceny stanu elementów uktadu hamulcowego. W artykule przedstawiono możliwości określenia zużycia elementów ciernych kolejowego hamulca tarczowego na podstawie analiz sygnałów przyspieszeń drgań generowanych przez oktadziny cierne hamulca. W artykule przedstawiono regresyjne modele diagnostyczne [15] bazujace na analizie sygnałów przyspieszeń drgań w dziedzinie amplitud oraz $w$ dziedzinie częstotliwości.
\end{abstract}

Stowa kluczowe: kolejowy hamulec tarczowy, diagnostyka wibroakustyczna, charakterystyki amplitudowe, analiza widmowa.

\section{Introduction}

Vibrations generated by the braking systems, both in rail vehicles or car have been widely analyzed and presented in the literature for several decades. Most of the articles raise the problems abrasive wear [4, 14], but noise and vibration to disrupt the process of braking and comfort during this process [12]. There are many models that describe the vibrations generated by the braking systems which include Rudolph and Popp model [17], North [16] and Millner [21] (flutter binary model In contrast, a separate issue is the brake vibroacoustic diagnostics designed to diagnose selected brake components. The number of articles in this area is much smaller, which means that the issue of vibroacoustic diagnostics of the braking system is developed by few researchers. Works $[10,18]$ presents the possibility of using vibrations generated by the brakes to assess the condition of the brake friction pair, both in design and during utilization of the brakes. Data acquired during tests certified on the braking positions (In Poland there are only two positions for the research of railway braking systems on IPS TABOR in Poznan and Warsaw IK) and during driving tests are used for modelling the braking process, as shown in $[1,11]$ or predicting the damage [6].

While the diagnosis of the braking systems, the aim is to find the relationship between system condition and the diagnostic signal, according to the equation (1) [5]:

$$
S(\Theta)=\Phi[X(\Theta), Y(\Theta)]+Z(\Theta)
$$

where: $S(\Theta) \quad=\left\{s_{1}, s_{2}, \ldots, s_{n}\right\}$ - diagnostic signal vector,
$X(\Theta)=\left\{x_{1}, x_{2}, \ldots, x_{n}\right\}$ - condition parameters vector,

$Y(\Theta)=\left\{y_{1}, y_{2}, \ldots, y_{n}\right\}$ - control vector,

$Z(\Theta)=\left\{z_{1}, z_{2}, \ldots, z_{n}\right\}$ - disruption vector,

$\Theta \quad$-operating measure of obsolescence (time or distance)

$\Phi \quad-$ assignment operator.

To describe the signal vector $S(\Theta)=\left\{s_{1}, s_{2}, \ldots, s_{n}\right\}$ specifying the technical condition of the braking system we should use the working process parameters (eg. the braking torque) and the accompanying vibrations or noise.

The diagnostic problem of the disc brake system results from the brake working conditions and its location. In the case of railway vehicles, the disc brake is mounted on the wheel sets axle between the wheels (Fig. 1) and it is not visible while servicing the truck. Then

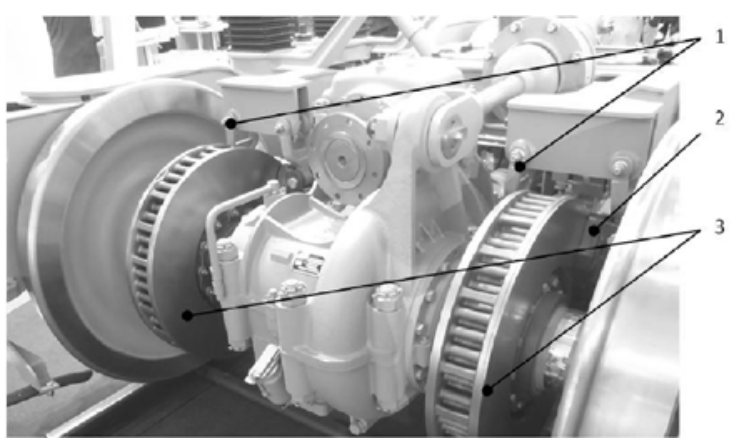

Fig. 1. Railway disc brake on the two-axle bogie: 1 - level mechanism, 2- friction pad, 3 - brake disc

(*) Tekst artykułu w polskiej wersji językowej dostępny w elektronicznym wydaniu kwartalnika na stronie www.ein.org.pl 
it is necessary to enter on the track with the manhole channel for the inspection of worn friction elements. In the case of cars we meet the pad wear sensor which is embedded in the friction material at a certain depth. After reaching the maximum of the permissible wear of the pad, most often about $2 \mathrm{~mm}$, and after contact of the sensor with the metal disc, an electrical circuit is being closed, causing the lit of the control light for the wear of the friction pads.

The aim of the research is to use the vibration signal generated by the friction pads in the assessment of their wear and setting the characteristics in the field of amplitudes and frequency during the tests on inertia braking position.

\section{Methodology and research object}

The research was carried out at internal station in Institute IPS TABOR in Poznan for tests of railway brakes. A brake disc type $590 \times 110$ with ventilation vanes and three sets of pads type 175 FR20H. 2 made by Frenoplast constitute the research object. One set was new $-35 \mathrm{~mm}$ thick and two sets were worn to thickness of $25 \mathrm{~mm}$ and $15 \mathrm{~mm}$. A reasearch program 2B1 (II) according to [13] was applied. The braking was carried out from speed of $80 \mathrm{~km} / \mathrm{h}$ and it was the braking with the constant braking power $\mathrm{P}=45 \mathrm{~kW}$. During the research pad's pressures to disc $N$ of $28 \mathrm{kN}$ was realized as well as braking masses per one disc of $\mathrm{M}=6.7 \mathrm{~T}$. Vibration converters were mounted on pad calipers with a mounting metal tile, which is presented in Fig. $2 \mathrm{a}$ and $2 \mathrm{~b}$.
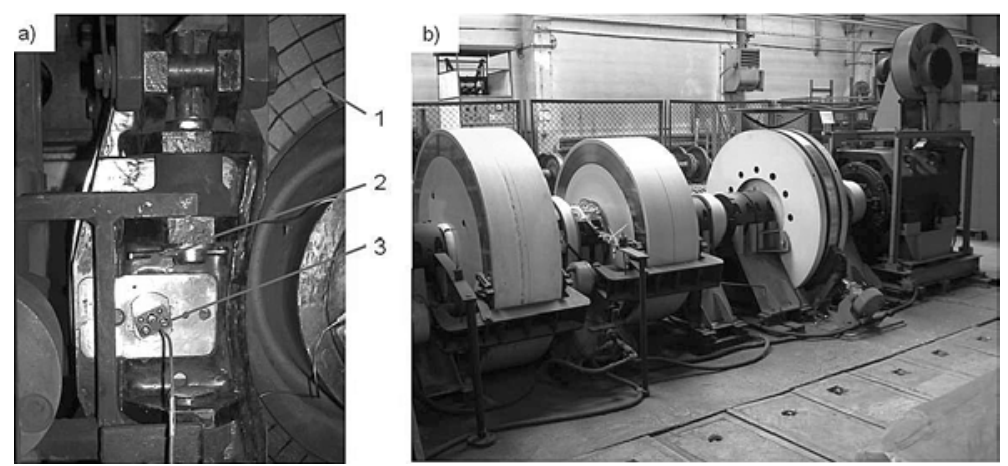

Fig. 2. Inertial station for tests of railway brakes: a) view of calliper with accelerometr, b) view of inertial station during diagnostic tests; 1- brake disc, 2-caliper, 3accelerometer

During the tests recorded vibration acceleration signals in one direction, i.e. perpendicular to the friction surface of the brake disc. To acquire vibration signal a measuring system consisting of piezoelectric vibration accelerations converter and measuring case type $\mathrm{B} \& \mathrm{~K}$ 3050-A-060 with system software PULSE 16.0 was used. Figure 3 presents the view of the measurement set.

Brüel\&Kjær's vibration converters type 4504 were selected on the basis of instructions included in paper [3]. The linear frequency

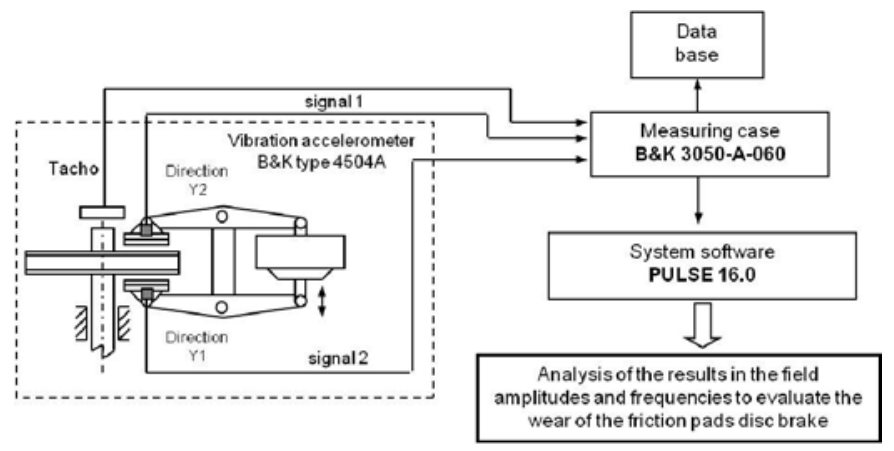

Fig. 3. Diagram of procedures for the selection signal of vibration acceleration at the time of diagnosis of wear of the friction rail brake disc

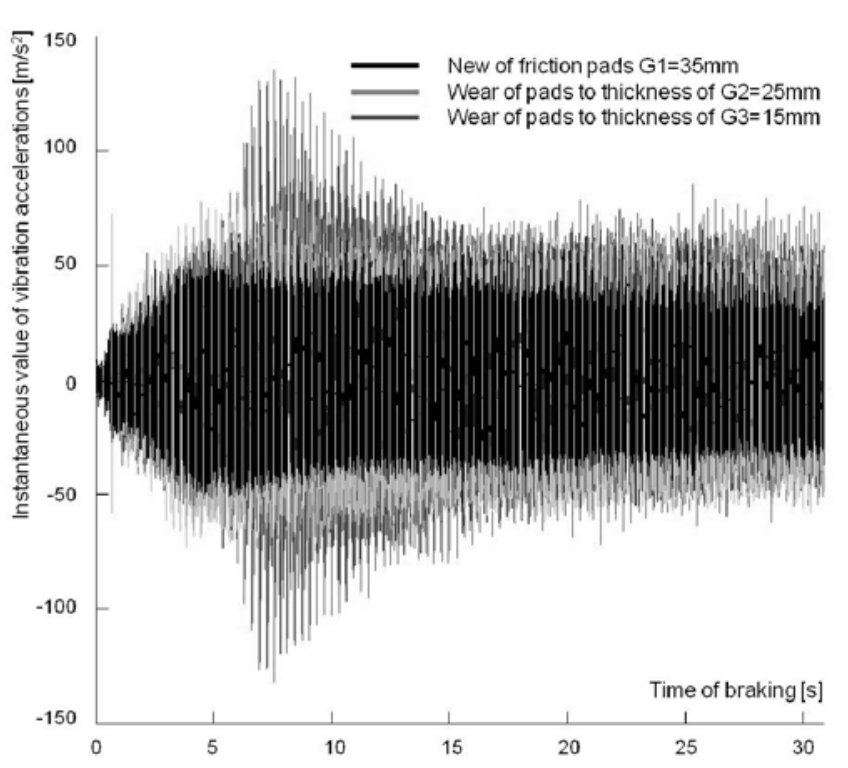

Fig. 4. Signal of vibration accelerations registered on pad caliper for different thickness of pads during braking with the constant braking power

of converter transit amounted to $5 \mathrm{kHz}$. Sampling frequency was set at $131 \mathrm{kHz}$. This means that the frequency that was subject of the analysis in accordance with Nyquist relation amounted to $65 \mathrm{kHz}$. Do not changed other parameters which braking descent speed train, pressure pads to disc, the brake weight and braking time. At the same time, changes occurring in the instantaneous amplitude of vibration acceleration. This research was carried out in accordance with principles of active experiment. After carrying out a series of brakings the friction pads were changed (without changing the other parameters of braking) and values of instantaneous vibration accelerations were registered. Figure 4 shows the time analysis of instantaneous vibration acceleration recorded at the pads of friction during braking on a slope. Then the recorded signals were analyzed in the domain amplitude and frequency.

\section{Analysis of the results in the amplitude domain}

In domain of amplitudes, the most common are the point parameters, which are used to describe displacement signals, speed signals and signals of vibration accelerations. Characterizing vibration signal with one number is an advantage of point parameters, thanks to which it is easy to define changes in vibroacoustic signal resulting from changes in technical condition of the tested object.

Used measurement point in the diagnosis of vibroacoustic, according to the paper [18], is divided into dimensional and dimensionless. To diagnose the wear of friction pads of railway brake the following dimensional point parameters are applied (2):

$$
A_{A V E R A G E}=\frac{1}{T} \int_{0}^{T} \mid s(t) d t
$$

where: $T-$ average time,

$s(t)$ - instantaneous value of vibration accelerations.

average amplitude, described with dependence (3):

$$
A_{R M S}=\sqrt{\frac{1}{T} \int_{0}^{T}[s(t)]^{2} d t}
$$


square amplitude, describe with dependence (4):

$$
A_{\text {SQUARE }}=\left[\frac{1}{T} \int_{0}^{T}|s(t)|^{\frac{1}{2}} d t\right]^{2}
$$

peak amplitude, described with equation (5):

$$
A_{P E A K}=\left[\frac{1}{T} \int_{0}^{T}|s(t)|^{\infty} d t\right]^{\frac{1}{\infty}}
$$

Before calculating point parameters from signals of vibration accelerations in program Matlab, a preliminary processing of signal in time domain was carried out. The reason of this processing was to select from the whole registered signal a part connected only with
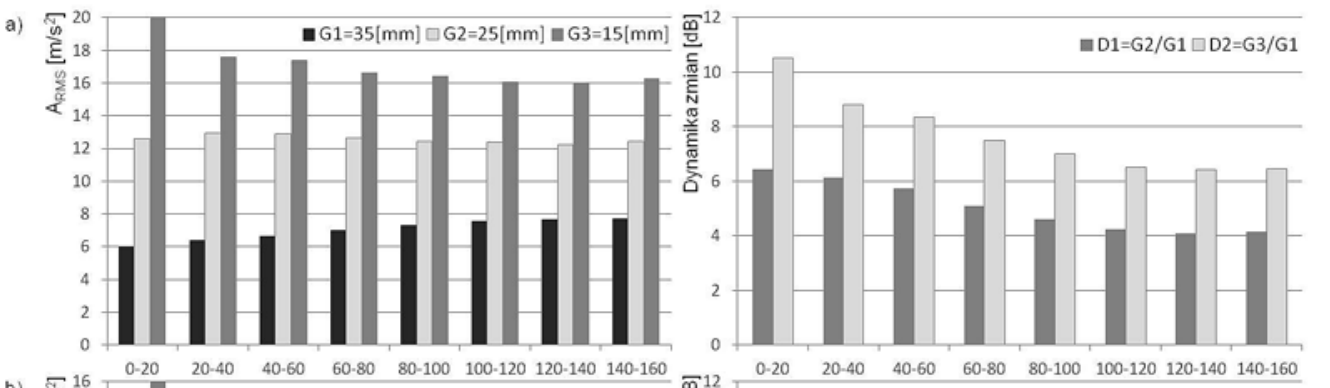

b)
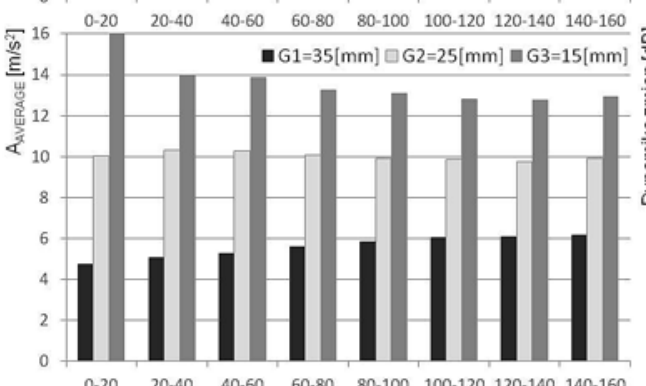

c)
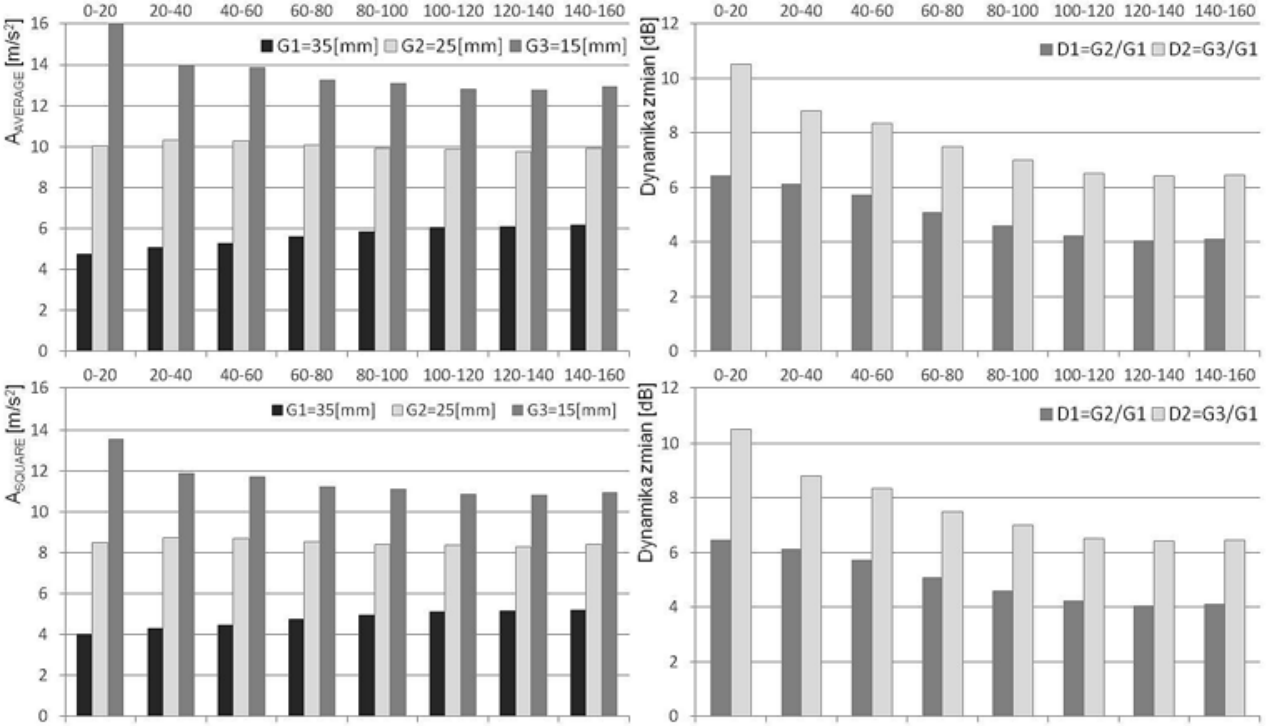

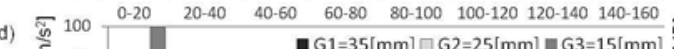

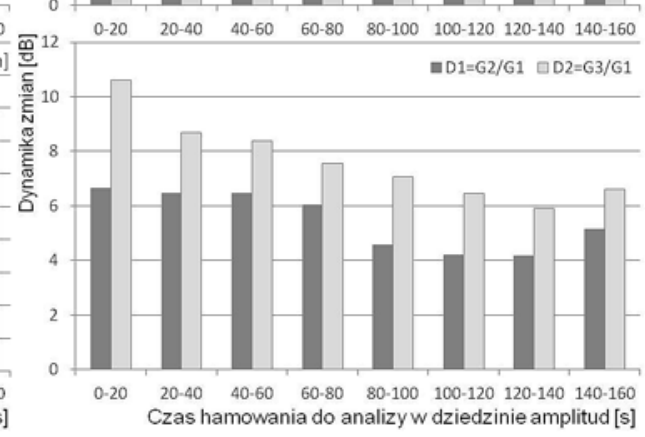

braking process. This process was also carried out to obtain required dynamics of changes essential for diagnostic purposes. Defining dependence of friction pad's thickness on selected point parameters was carried out through determining dynamics of changes for a certain parameter, which is presented in dependence (6) [9]:

$$
D=20 \lg \left(\frac{A_{2}}{A_{1}}\right)
$$

where: $A_{1}$ - the value of point parameter determined for pad $G_{3}$ or $G_{2}$, $A_{2}$ - the value of point parameter determined for pad $G_{1}$.

Figure 5 present dependence of (RMS) value, average value, square value and peak value of vibration accelerations measure in direction $Y_{2}$ on time brakings during braking with constant power $P$ for various values of pad wear $G$ with v $=80 \mathrm{~km} / \mathrm{h}$.

The test results after applying the dependences describing measurement point (2-5), and the dependence of the speed of change (6) shown in Table 1. Based on the results, it was found that the most sensitive diagnostic parameter defined the dynamics of change for assessment of wear on the friction pads, obtained for the measurement of vibration acceleration $Y_{2}$ for all measurement points.

The analysis of results of vibration tests showed that obtaining dependence of friction pads' thickness on the value of point parameters is possible by measuring vibration in directions $Y_{1}$ and $Y_{2}$ on a accelerometer mounted from the side of brake cylinder's case and brake cylinder's piston rod.

Braking time to analyze in the field amplitudes is divided into 8 periods of time every 20 seconds to the total time of analysis $t=160 \mathrm{~s}$. The analysis in the field amplitudes in further braking times, does not affect the improvement of diagnostic parameter.

Figure 6 and 7 presents dependence of friction pad's thickness of disc brake $G$ on point parameters of vibration accelerations. For RMS, Average, Square and Peak value of point parameter, also obtained from measurement in direction $Y_{2}$ by using linear approximating functions described with dependences (7-10) for five speeds at the beginning of braking, the following equations defining friction pads' thickness were introduced:

Fig. 5. Dependence of selected point paramiters and dynamic of changes of the wear of friction pads: a) RMS value $\left.A_{R M S}, b\right)$ average value $\left.A_{A V E R A G E}, c\right)$ square value $A_{\text {SQUARE }}$, d) square value $A_{P E A K}$ 
Table 1. Value of selected point paramiters and dynamics of changes in direction $Y_{1}$ and $Y_{2}$ for the first time braking from 0 to 20 seconds

\begin{tabular}{|c|c|c|c|c|c||}
\hline \multirow{2}{*}{ Point parameters } & \multicolumn{5}{|c|}{ Measurement of vibrations in direction $Y_{1}$} \\
\cline { 2 - 6 } & Thickness of $35 \mathrm{~mm}$ & Thickness of $25 \mathrm{~mm}$ & Thickness of $15 \mathrm{~mm}$ & $\begin{array}{c}\text { Dor pads with } \\
\text { thicknesses of } 35 \\
\mathrm{~mm} \text { and } 25 \mathrm{~mm}\end{array}$ & $\begin{array}{c}\text { For pads with } \\
\text { thicknesses of } 35 \\
\mathrm{~mm} \text { and } 15 \mathrm{~mm}\end{array}$ \\
\hline$A_{\text {RMS }}$ & 6,42 & 12,42 & 14,50 & 5,73 & 7,08 \\
\hline$A_{\text {AVERAGE }}$ & 5,11 & 9,90 & 11,53 & 5,75 & 7,05 \\
\hline$A_{\text {SQARE }}$ & 4,32 & 8,39 & 9,76 & 5,76 & 7,07 \\
\hline$A_{\text {PEAK }}$ & 33,51 & 63,17 & 91,58 & 5,50 & 8,73 \\
\hline$A_{\text {RMS }}$ & 6,00 & 12,58 & 20,15 & 6,42 & 10,52 \\
\hline$A_{\text {AVERAGE }}$ & 4,77 & 10,03 & 16,02 & 6,44 & 10,51 \\
\hline$A_{\text {SQARE }}$ & 4,04 & 8,49 & 13,55 & 6,46 & 10,51 \\
\hline$A_{\text {PEAK }}$ & 31,46 & 67,76 & 106,88 & 6,66 & 10,64 \\
\hline
\end{tabular}

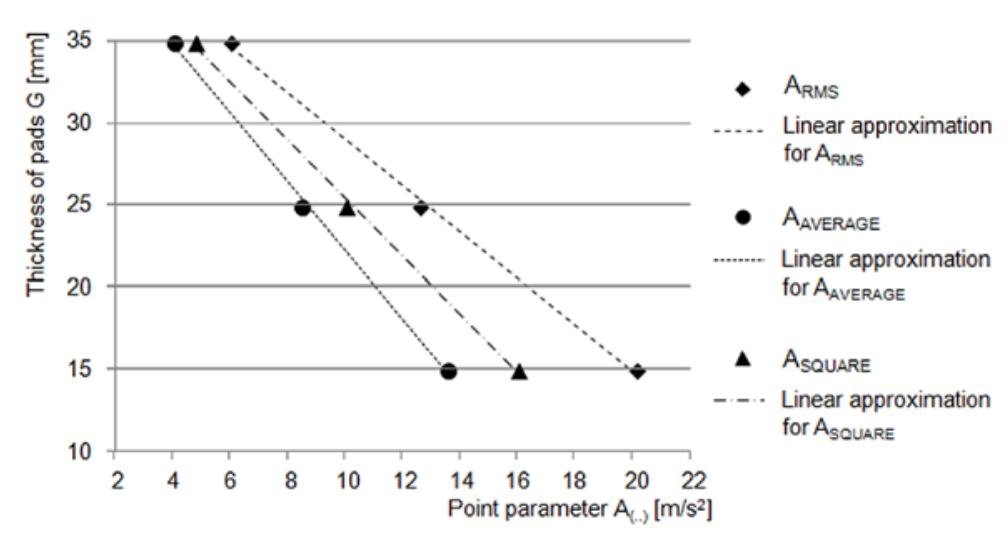

Fig. 6. Dependence of pad's thickness in function of point parameters $\left(A_{R M S}, A_{A V E R A G E}\right.$, $\left.A_{S Q U A R E} v a l u e\right)$ of vibrations accelerations for measurement in the $Y_{2}$ direction

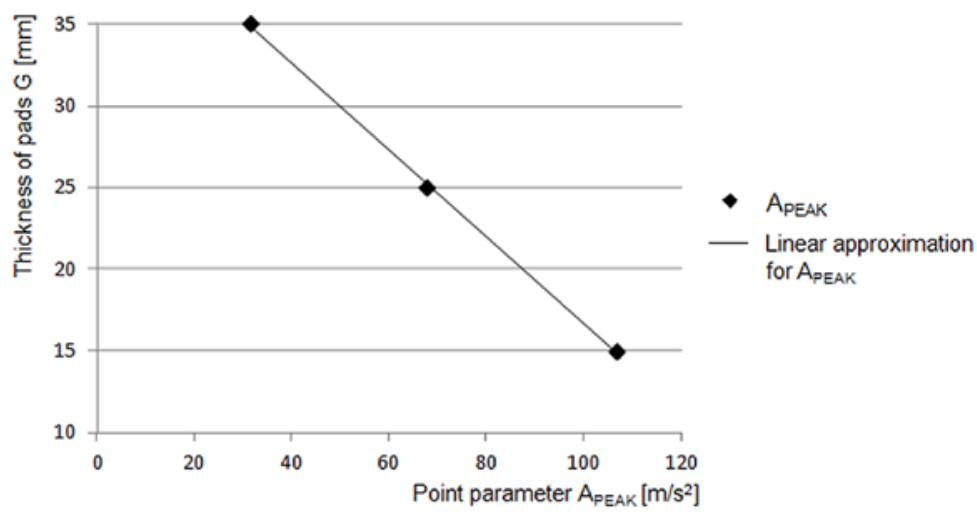

Fig. 7. Dependence of pad's thickness in function of point parameters $A_{P E A K}$ value of vibrations accelerations for measurement in the $Y_{2}$ direction

$$
G=-1,4115 \cdot A_{R M S}(Y 1, t=0-20 s)+43,224 R^{2}=0,99
$$

$$
G=-1,7765 \cdot A_{A V E R A G E}(Y 2, t=0-20 s)+43,251 R^{2}=0,99
$$

$$
G=-2,1006 \cdot A_{\text {SQUARE }(Y 2, t=0-20 s)}+43,261 R^{2}=0,99
$$

$$
G=-0,2651 \cdot A_{P E A K}(Y 2, t=0-20 s)+43,221 R^{2}=0,99
$$

where:

$$
\begin{array}{ll}
G & - \text { thickness of pad }[\mathrm{mm}], \\
A_{(. .)} & - \text {point parameters value of vibration } \\
& \text { accelerations }\left[\mathrm{m} / \mathrm{s}^{2}\right] .
\end{array}
$$

The inaccuracy of the linear regression models described dependencies (7-10) present table 2.

Table 2. Error in \% in the application models in estimating linear regression actual thickness of brake pad

\begin{tabular}{||c|c|c|c||}
\hline \multicolumn{4}{|c||}{ Measurement of vibrations in direction $Y_{2}$} \\
\hline $\begin{array}{c}\text { Point param- } \\
\text { eters }\end{array}$ & $\begin{array}{c}\text { Point param- } \\
\text { eters }\end{array}$ & $\begin{array}{c}\text { Point param- } \\
\text { eters }\end{array}$ & $\begin{array}{c}\text { Point param- } \\
\text { eters }\end{array}$ \\
\hline$A_{\text {RMS }}$ & 0,72 & 1,88 & 1,47 \\
\hline$A_{\text {AVERAGE }}$ & 0,67 & 1,73 & 1,38 \\
\hline$A_{\text {SQARE }}$ & 0,64 & 1,67 & 0,83 \\
\hline$A_{\text {PEAK }}$ & 0,37 & 0,99 & 0,89 \\
\hline
\end{tabular}

The analysis of results of research in amplitude domain showed that on the basis of the analysed in this article point parameters it is possible to diagnose the wear of friction pads independently during braking with constant braking power $\mathrm{P}=45 \mathrm{~kW}$. The dynamics of changes of RMS values of vibration accelerations for pads: $G_{1}, G_{2}$ and $G_{3}$ can be found in the range between 5 and $7 \mathrm{~dB}$ for direction $Y_{1}$ and 6 to $10 \mathrm{~dB}$ for direction $Y_{2}$ measurement of vibrations on railway disc brake.

\section{Analysis of the results in the frequency domain}

The amapurpose of spectrum analysis of signals of vibration accelerations was to determine frequency bands connected with change of pad's thickness during operation of braking system. Figure 8 and 9 presents exemplary amplitude spectra of vibration accelerations for various pad's thicknesses received during braking with constant braking power from speed of $80 \mathrm{~km} / \mathrm{h}$. The figure 10 and 11 presents exemplary amplitude spectra of vibration accelerations of the use of band-pass filter. The scope of the filter has been set to $4600-4800 \mathrm{~Hz}$, because in this area there is a dependency of amplitude of vibration on thickness of friction pads.

Table 3 presents frequency range, in which dependence of amplitude value of vibration accelerations on the wear of pads is observed. Additionally, dynamics of changes according to dependence (6) of an examined diagnostic parameter for a certain frequency band and at 

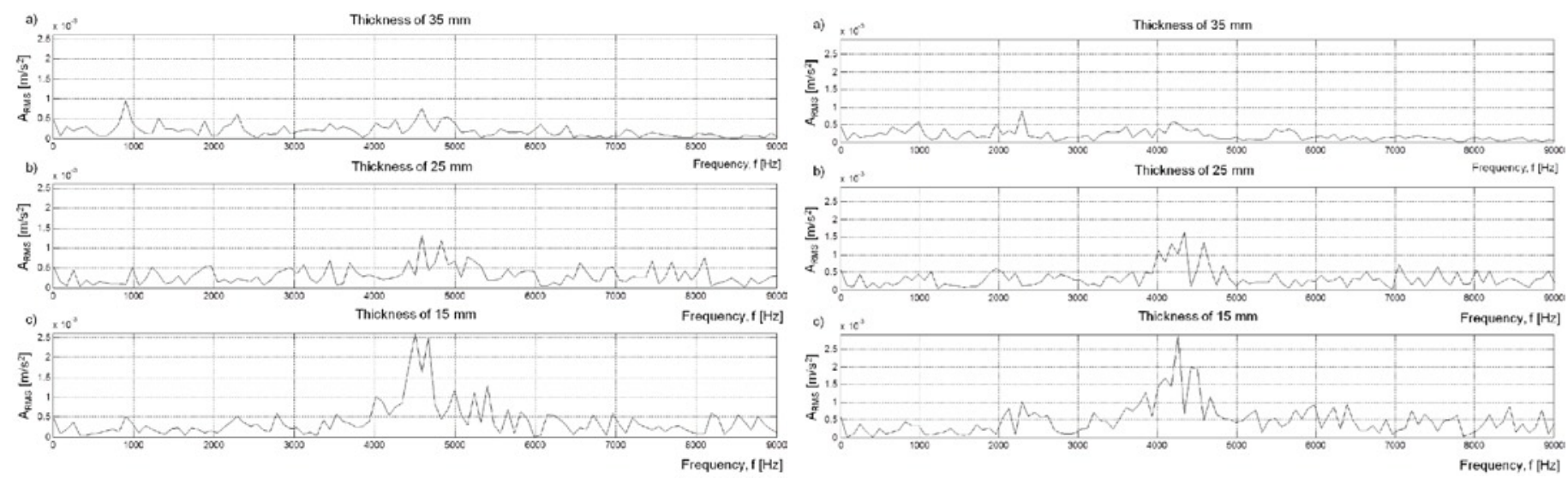

Fig. 8. Dependence of amplitude of vibration accelerations on frequencies for different pad's thicknesses during braking with constant braking power from speed of $80 \mathrm{~km} / \mathrm{h}$ in direction $Y_{1}$ : a) pad's thickness $G_{1}=35 \mathrm{~mm}$, b) pad's thickness $G_{2}=25 \mathrm{~mm}, \mathrm{c}$ ) pad's thickness $G_{3}=15 \mathrm{~mm}$

Fig. 9. Dependence of amplitude of vibration accelerations on frequencies for different pad's thicknesses during braking with constant braking power from speed of $80 \mathrm{~km} / \mathrm{h}$ in direction $Y_{2}:$ a) pad's thickness $G_{1}=35 \mathrm{~mm}, \mathrm{~b}$ ) pad's thickness $G_{2}=25 \mathrm{~mm}$, c) pad's thickness $G_{3}=15 \mathrm{~mm}$
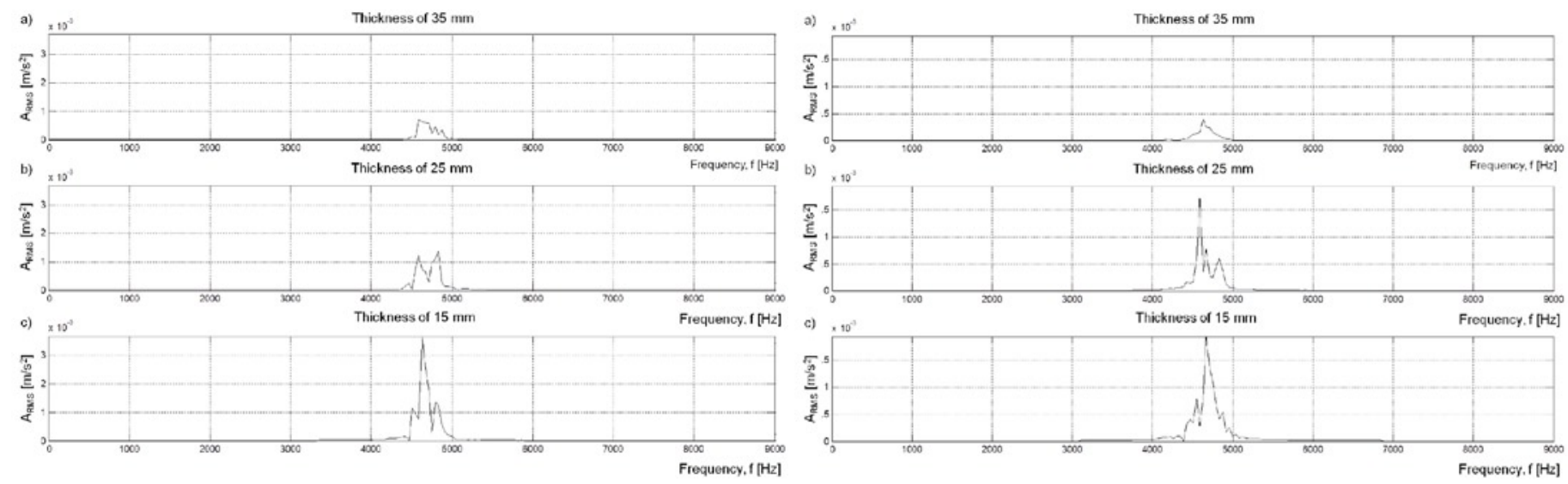

Fig. 10. Dependence of amplitude of vibration accelerations on frequencies with band-pass filter to 4600-4800Hz for different pad's thicknesses in direction $Y_{1}$ : a) pad's thickness $G_{1}=35 \mathrm{~mm}$, b) pad's thickness $G_{2}=25 \mathrm{~mm}, \mathrm{c}$ ) pad's thickness $G_{3}=15 \mathrm{~mm}$

Fig. 11. Dependence of amplitude of vibration accelerations on frequencies with band-pass filter to 4600-4800Hz for different pad's thicknesses in direction $Y_{2}$ : a) pad's thickness $G_{1}=35 \mathrm{~mm}$, b) pad's thickness $G_{2}=25 \mathrm{~mm}, \mathrm{c}$ ) pad's thickness $G_{3}=15 \mathrm{~mm}$

Table 3. Results of frequency analysis of vibration acceleration signals, brake caliper with brake pads

\begin{tabular}{|c|c|c|c|c|c|c|}
\hline \multicolumn{7}{|c|}{ Measurement of vibrations in direction $Y_{1}$} \\
\hline \multirow{2}{*}{$\begin{array}{l}\text { Frequency } \\
\qquad \mathrm{Hz}\end{array}$} & \multicolumn{3}{|c|}{$\begin{array}{l}\text { RMS from band frequency } \\
\mathrm{m} / \mathrm{s}^{2}\end{array}$} & \multicolumn{2}{|c|}{$\begin{array}{l}\text { Dynamics of changes } \\
\qquad \mathrm{dB}\end{array}$} & \multirow{2}{*}{$\begin{array}{l}\text { Correlation } \\
\text { coefficient }\end{array}$} \\
\hline & Thickness of $35 \mathrm{~mm}$ & Thickness of $25 \mathrm{~mm}$ & Thickness of $15 \mathrm{~mm}$ & $\begin{array}{l}\text { For pads with thick- } \\
\text { nesses of } 35 \mathrm{~mm} \text { and } \\
25 \mathrm{~mm}\end{array}$ & $\begin{array}{l}\text { For pads with thick- } \\
\text { nesses of } 35 \mathrm{~mm} \text { and } \\
15 \mathrm{~mm}\end{array}$ & \\
\hline $4600-4800$ & $1,27 \cdot 10^{-3}$ & $1,77 \cdot 10^{-3}$ & $5,00 \cdot 10^{-3}$ & 2,92 & 11,92 & 0,922 \\
\hline \multicolumn{7}{|c|}{ Measurement of vibrations in direction $Y_{2}$} \\
\hline $4600-4800$ & $0,56 \cdot 10^{-3}$ & $2,02 \cdot 10^{-3}$ & $2,63 \cdot 10^{-3}$ & 2,29 & 13,38 & 0,973 \\
\hline
\end{tabular}

a certain speed at the beginning of braking and values of correlation coefficients for linear dependence of amplitude value of vibration accelerations on examined friction pad's thicknesses is presented.

Figure 12 present dependence of (RMS) value of vibration accelerations in direction $Y$ on braking speed $\mathrm{v}=80 \mathrm{~km} / \mathrm{h}$ during braking with the constant braking power for various values of the wear of pad $G$.

Figure 13 presents dependence of friction pad's thickness of disc brake $G$ on RMS value of vibration accelerations $A_{\text {RMS }}$ in considered frequency bands $4600-4800 \mathrm{~Hz}$. For both directions of vibration (i.e. for the staff of the friction pads is connected with the lever to the housing of the brake cylinder and the holder connected to the lever on the piston brake cylinders) have been approximated a linear function depending on the thickness of the lining of the effective value of the vibration acceleration (relation (11) and (12)).

$$
\begin{gathered}
G=-4546,8 \cdot A_{R M S(Y 1,4600-4800)}+37,201 R^{2}=0,85 \\
G=-9150 \cdot A_{R M S}(Y 2,4600-4800)+40,924 R^{2}=0,95
\end{gathered}
$$

where: $G \quad-$ thickness of pad [mm],

$A_{R M S}-$ RMS value from band $4600-4800 \mathrm{~Hz}$ frequency $\left[\mathrm{m} / \mathrm{s}^{2}\right]$. 


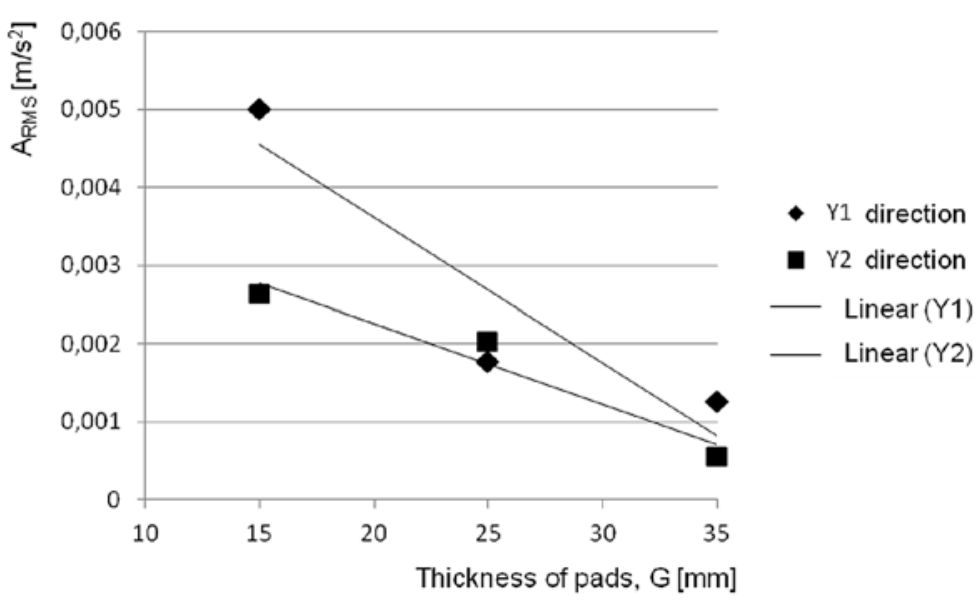

Fig. 12. Dependence of RMS value of vibration accelerations on braking speed $v=80 \mathrm{~km} / \mathrm{h}$ during braking with the constant braking power for various values of the wear of pad $G$

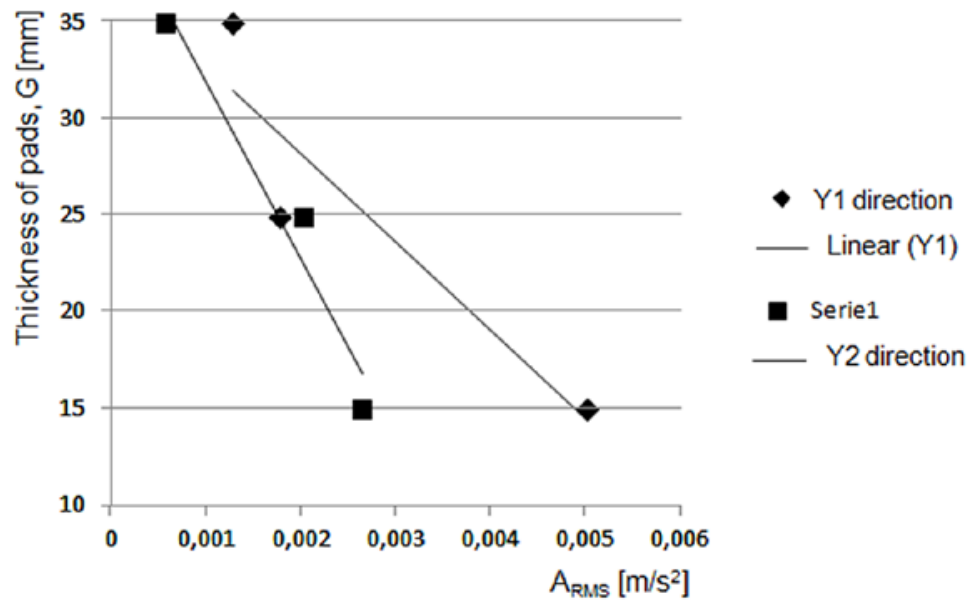

Fig. 13. Dependence of pad's thickness in function of RMS value of vibrations accelerations for frequency band $4600-4800 \mathrm{~Hz}$

Table 4. Error in \% in the application models in estimating linear regression actual thickness of brake pad

\begin{tabular}{|c|c|c|c|}
\hline \multicolumn{4}{|c|}{ Measurement of vibrations in direction $Y_{1}$} \\
\hline $\begin{array}{c}\text { Frequency } \\
\mathrm{Hz}\end{array}$ & $\begin{array}{c}\text { For thickness of pad } \\
\mathrm{G}_{1}=35 \mathrm{~mm}\end{array}$ & $\begin{array}{c}\text { For thickness of pad } \\
\mathrm{G}_{2}=25 \mathrm{~mm}\end{array}$ & $\begin{array}{c}\text { For thickness of pad } \\
\mathrm{G}_{3}=15 \mathrm{~mm}\end{array}$ \\
\hline $4600-4800$ & 11,3 & 16,5 & 3,9 \\
\hline \multicolumn{4}{|c|}{ Measurement of vibrations in direction $Y_{2}$} \\
\hline $4600-4800$ & 2,2 & 11,5 & 12,2 \\
\hline
\end{tabular}

The inaccuracy of the linear regression models described dependencies (11 and 12) present table 4.

Analysis of the results in the frequency domain showed that the analyzed frequency band $4600-4800 \mathrm{~Hz}$ it is possible to diagnose wear of the friction pads based on designated this band vibration acceleration during braking with constant power (during the descent of the train at a constant speed). Dynamics of changes in RMS value of vibration acceleration for pads $G_{1}, G_{2}$ and $G_{3}$ is in the range of 2-13 dB.

\section{Conclusions}

Position diagnostic tests have shown that it is possible to diagnose the consumption of the disc brake friction pads, by analyzing the instantaneous value of the vibration acceleration holders with the pads in the field of amplitudes. For the purposes of the pads wear diagnosis, the effective value of $A_{R M S}$, the average value $A_{A V E R A G E}$, the square value $A_{S Q U A R E}$ or peak value $A_{\text {peak }}$ should be used. With the dimensionless quantity (point measurement coefficient), satisfactory results are obtained by using the crest factor calculated from the relationship of peak to rms. The vibration acceleration signal analysis showed that the highest growth of changes of considered diagnostic parameter, resulting from the condition change, is achieved for the first braking period (braking time 20 seconds). During this period, the highest value for the worn pad to a thickness of $15 \mathrm{~mm}$, and the lowest value for the new pad (run in) with a thickness of $35 \mathrm{~mm}$ are obtained. Further breaking periods, higher than 20 seconds, cause the decrease in the rate of 'changes.

Changes in the vibration acceleration measurement point, according to the usage of braking pads, are visible regardless of mounting the vibration transducer at the brake holder from the side of the rod or from the housing side of the brake cylinder and irrespective to the type of the brake disc.

For the analysis in the field of amplitudes, the dynamics of changes is $6-10 \mathrm{~dB}$ for the 590 disc. By using the measurement of vibration acceleration point under consideration , the diagnostic models can be used to determine the consumption of the friction pads. The maximum error of the friction pad thickness for the present three-pads thicknesses does not exceed $2 \%$ for the analyzed brake disc.

Tests measuring the vibration acceleration of the brake holders in the frequency domain, have also shown that it is possible to find a frequency band, in which the dependence of the effective value of the vibration acceleration $\mathrm{A}_{\mathrm{RMS}}$ (equation (3)) from the different pads in the considered speed range during the train run with enabled brakes are observed. The dependence of the effective value of vibration acceleration from the wear of the friction pads occurs for the $4600-4800 \mathrm{~Hz}$ frequency band. It is the band allowing to diagnose the wear of the friction pads both during braking on 590 disc type with the power of $\mathrm{P}=45$ $\mathrm{kW}$ and braking on 640 disc type with constant power $\mathrm{P}=55 \mathrm{~kW}$.

Both vibration analysis in the field of amplitudes and frequency allows for the friction elements evaluation. Frequency analysis allows for greater analysis of the dynamics of changes in terms of amplitude. However, in both cases, it is greater than $6 \mathrm{~dB}$ for the worn pad to a thickness of $15 \mathrm{~mm}$. However, the analysis of amplitudes by using the measurement point is simpler with respect to the application of frequency analysis because it averages the whole braking process to a single value.

Analyzing the current device diagnostic disc brake friction elements, the method allows vibroacoustic continuously evaluate the condition of the friction linings terms of wear indicators that signal achievement only permissible pad wear of about $2-3 \mathrm{~mm}$. The use of vibration transducers on the brake mountings enables diagnosis of wear of the friction linings in the whole process of use. Then read the pad wear during periodic inspections or the desktop will allow the vehicle to make a decision about the further use of the vehicle particularly in international traffic, where the replacement of the pad limit their consumption will be impossible or very time-consuming. 
In the further works it is planned to check the developed method for assessing the wear of the friction pads on the worn discs (during the research new brake discs were used). It was made in order to eliminate the influence of the friction rings condition on the result of the diagnosis with the use of regression vibration diagnostics models.

It should, however, emphasize that vibroacoustic diagnostics based on the analyzes in the domain amplitudes and frequencies is widely used in the diagnosis of internal combustion engines [7, 20], bearing units rotating machinery [8] and in the automotive industry. In many cases, vibration transducers are built directly into the device from the cable output signal to a central computer. In addition, the diagnosis of the type of technical systems FFT analysis are expanded for analysis of the time-frequency [19].

The project is funded by the National Centre for Research and Development, program LIDER V, contract No. LIDER/022/359/L-5/13/ $N C B R / 2014$

\title{
References
}

1. Baranowski P, Damaziak K, Małachowski J. Brake system studies using numerical methods. Eksploatacja i Niezawodnosc - Maintenance and Reliability 2013; 15 (4): 337-342.

2. Betancourt S.J, Cruz A, Toro: Friction and wear in sliding contact of cast iron against phenolic resin composites reinforced with carbonaceous fibres from plantain fibre bundles; Lubrication Science 2013, 25: 163-172, http://dx.doi.org/10.1002/ls.1186.

3. Brüel\&Kjær. Product data. Piezoelectric Accelerometer Miniature Triaxial Delta Tron Accelerometer - Type 4504A. BP 1451-13 04/06: 2.

4. Collignon M, Regheere G, Cristol A.L, Desplanques Y, Balloy D. Braking performance and influence of microstructure of advanced cast irons for heavy goods vehicle brake discs; Journal of Engineering Tribology; 227(8): 930-940; 2013, http://dx.doi.org/10.1177/1350650113484212.

5. Cempel C. Podstawy wibroakustycznej diagnostyki maszyn. WNT Warszawa 1982.

6. Gill A, Kadziński A. The determination procedure of the onset of the object wear-out period based on monitoring of the empirical failure intensity function. Eksploatacja i Niezawodnosc - Maintenance and Reliability 2015; 17 (2): 282-287, http://dx.doi.org/10.17531/ ein.2015.2.16.

7. Glowacz A. Recognition of Acoustic Signals of Loaded Synchronous Motor Using FFT, MSAF-5 and LSVM. Archives of Acoustics 2015, 40 (2): 197-203, http://dx.doi.org/10.1515/aoa-2015-0022.

8. Glowacz A. Diagnostics of DC and Induction Motors Based on the Analysis of Acoustic Signals. Measurement Science Review 2014, 14 (5): 257-262, http://dx.doi.org/10.2478/msr-2014-0035.

9. Gryboś R. Drgania maszyn. Wydawnictwo Politechniki Śląskiej, Gliwice 2009: 214.

10. Hoguet T. Testy hamulców w firmie Bosch. Brüel \& Kjær Magazine, 2007, nr 2: 22-24.

11. Kamiński Z, Kulikowski K. Determination of the functional and service characteristics of the pneumatic system of an agricultural tractor with mechanical brakes using simulation methods. Eksploatacja i Niezawodnosc - Maintenance and Reliability 2015 ; 17 (3): 355-364, http://dx.doi.org/10.17531/ein.2015.3.5.

12. Kinkaid N.M, O'Reilly O. M, Papadopoulos P. Automotive disc brake squeal. Journal of sound and vibration 267 (2003) 105-166. Department of Mechanical Engineering, University of California, Berkeley, USA, http://dx.doi.org/10.1016/S0022-460X(02)01573-0.

13. Kodeks UIC 541-3. Hamulec-Hamulec tarczowy i jego zastosowanie. Warunki dopuszczenia okładzin hamulcowych. Wydanie 6, listopad 2006.

14. Meierhofer A, Hardwick C, Lewis R, Six K, Dietmaier P. Third body layer-experimental results and a model describing its influence on the traction coefficient. Wear 2014; 314: 148-154, http://dx.doi.org/10.1016/j.wear.2013.11.040.

15. Niziński S, Michalski R. Diagnostyka obiektów technicznych. Wydawnictwo i Zakład Poligrafii Instytutu Technologii Eksploatacji, Radom, 2002.

16. North M,R. Disc brake squeal — a theoretical model. Technical Report 1972/5, Motor Industry Research Association, Warwickshire, England, 1972.

17. Rudolph M, Popp K. Brake squeal, in: K. Popp (Ed.), Detection, Utilization and Avoidance of Nonlinear Dynamical Effects in Engineering Applications: Final Report of a Joint Research Project Sponsored by the German Federal Ministry of Education and Research, Shaker, Aachen, 2001: 197-225.

18. Sawczuk W, Szymański M,G. Application of selected time and amplitude characteristics of vibration Signac to diagnose railway disc brake. Modern Electric Traction - Vehicles: 129-141.

19. Szymański G.M, Josko M, Tomaszewski F, Filipiak R. Application of time-frequency analysis to the evaluation of the condition of car suspension. Mechanical Systems and Signal Processing 2015; 58-59: 298-307, http://dx.doi.org/10.1016/j.ymssp.2014.12.017.

20. Szymański G.M, Tomaszewski F. Diagnostic of automatic compensators of valve clearance in combustion engine with the use of vibration signal. Mechanical Systems and Signal Processing 2016; 68-69: 479-490, http://dx.doi.org/10.1016/j.ymssp.2015.07.015.

21. Ścieszka S.F. Hamulce cierne. Zagadnienia materiałowe, konstrukcyjne i tribologiczne. Wydawnictwo Gliwice-Radom $1998: 15$.

\author{
Wojciech SAWCZUK \\ Institute of Combustion Engines and Transport \\ Poznan University of Technology \\ ul. Piotrowo 3, 60-965 Poznan, Poland \\ E-mail: wojciech.sawczuk@put.poznan.pl
}

